\title{
Mesenchymal stem cells promote augmented response of endogenous neural stem cells in spinal cord injury of rats
}

\section{Células-tronco mesenquimais ampliam a resposta de células-tronco neurais endógenas no trauma da medula espinhal em ratos}

\author{
Marta Rocha Araujo ${ }^{1}$; Pablo Herthel Carvalho²; Taís Silva de Paula ${ }^{1}$; \\ Bárbara Silva Okano²; Ricardo Junqueira Del Carlo3; Rômulo Dias Novaes ${ }^{4}$; \\ Daise Nunes Queiroz da Cunha ${ }^{5 *}$; Clóvis Andrade Neves ${ }^{6}$
}

\begin{abstract}
Traumatic spinal cord injury results in severe neurological deficits, mostly irreversible. The cell therapy represents a strategy for treatment particularly with the use of stem cells with satisfactory results in several experimental models. The aim of the study was to compare the treatment of spinal cord injury (SCI) with and without mesenchymal stem cells (MSC), to investigate whether MSCs migrate and/or remain at the site of injury, and to analyze the effects of MSCs on inflammation, astrocytic reactivity and activation of endogenous stem cells. Three hours after SCI, animals received bone marrow-derived MSCs $\left(1 \times 10^{7}\right.$ in $1 \mathrm{~mL}$ PBS, IV). Animals were euthanized 24 hours, 7 and 21 days post-injury. The MSC were not present in the site of the lesion and the immunofluorescent evaluation showed significant attenuation of inflammatory response with reduction in macrophages labeled with anti-CD68 antibody (ED1), decreased immunoreactivity of astrocytes (GFAP+) and greater activation of endogenous stem cells (nestin + ) in the treated groups. Therefore, cell transplantation have a positive effect on recovery from traumatic spinal cord injury possibly due to the potential of MSCs to attenuate the immune response.
\end{abstract}

Key words: Cellular therapy. Neurosurgery. Stem cell.

\section{Resumo}

A lesão medular resulta em déficits neurológicos graves, a maioria irreversíveis. A terapia celular representa uma estratégia para o tratamento, especialmente com a utilização de células-tronco, com resultados satisfatórios em vários modelos experimentais. O objetivo do estudo foi comparar o tratamento de lesões da medula espinal (SCI), com e sem o uso de células-tronco mesenquimais (MSC), para investigar se as MSCs migram e/ou permanecem no local de lesão, e para analisar os efeitos de MSCs sobre a inflamação, reatividade astrocitária e ativação das células-tronco endógenas. Três horas depois da SCI, os animais receberam as MSC derivadas da medula óssea $\left(1 \times 10^{7} \mathrm{em} 1 \mathrm{~mL}\right.$ de PBS, IV). Os animais foram sacrificados 24 horas, 7 e 21 dias pós-lesão. As MSC não estavam presentes no

\footnotetext{
${ }^{1}$ Discentes, Departamento de Biologia Geral, Universidade Federal de Viçosa, UFV, Viçosa, MG, Brasil. E-mail: martaufv@, yahoo.com.br; tais.paula333@gmail.com

${ }^{2}$ Médicos Veterinários, Departamento de Veterinária, UFV, Viçosa, MG, Brasil. E-mail: pabloherthel@yahoo.com.br; barbaraokano@yahoo.com.br

3 Prof. Titular, Clínica Cirúrgica, UFV, Viçosa, MG, Brasil. E-mail: ricarlo@ufv.br

${ }^{4}$ Prof. Adjunto, Histologia, Instituto de Ciências Biomédicas, Departamento de Biologia Estrutural, Universidade Federal de Alfenas, UNIFAL, Alfenas, Brasil. E-mail: romuonovaes@yahoo.com.br

${ }^{5}$ Médica Veterinária, Pesquisa Clínica Veterinária, Zoetis, Brasil. E-mail: daisenunes@gmail.com

${ }^{6}$ Prof. Titular, Morfologia, Departamento de Biologia Geral, UFV, Viçosa, MG, Brasil. E-mail: caneves@ufv.br

* Author for correspondence
} 
local da lesão e a avaliação por imunofluorescência demonstrou atenuação significativa da resposta inflamatória com redução em macrófagos marcados com anticorpo anti CD68 (ED1), diminuição da imunorreatividade de astrócitos (GFAP +) e maior ativação das células-tronco endógenas (nestin+) nos grupos tratados. Assim, o transplante de células teve efeito positivo sobre a recuperação de lesão traumática da medula espinal, possivelmente devido ao potencial das MSCs para atenuar a resposta imunológica.

Palavras-chave: Células-tronco. Neurocirurgia. Terapia celular.

\section{Introduction}

Spinal cord lesions annually affect thousands of individuals of all age groups with high rates of mortality and chronic morbidity (SAUNDERS et al., 2009). The damage to the spinal cord after traumatic injury involves two events. The first mechanism is the initial injury that occurs at the time of trauma by either injury, compression, stretching or laceration involving the rupture and crushing of neural and vascular elements immediately. The second consists of endogenous secondary lesions, which are activated in response to the acute initial injury and may still occur within the first week after injury. Another consequence of spinal cord injury is the formation of glial scar that impedes axon regeneration. Astrocytes acquire hypertrophic characteristic followed by an increase in the production of intermediate filaments such as glial fibrillary acidic protein (GFAP) (SAHNI; KESSLER, 2010). With time most cell types including microglia, macrophages and progenitor cells are recruited resulting in scar formation.

Only a few surgical and pharmacological resources are available and none is able to totally reverse the neurological damage after spinal injury, but several clinical trials have been providing information about the regeneration of injured neurons and protection from further damage to the remaining cells. Transplantation with mesenchymal stem cells (MSC) is one of the promising options due to the ability of self-renewal and high proliferation capacity and are capable of differentiating into various cell types, including neurons (KERN et al., 2006), which may replace the injured nerve tissue or promote a favorable environment for tissue regeneration of the nervous system. Some studies indicate the ability of MSC to modulate the environment of the injured CNS and promote repair from the secretion of factors anti-inflammatory anti-apoptotic molecules and trophic factors able of promoting axonal growth and immunomodulation. Can also stimulate remyelination and angiogenesis (QUERTAINMONT et al., 2012).

The aim of this study was to transplant bone marrow derived mesenchymal stem cell by intravenous injection 3 hours after compression injury of the spinal cord to assess their possible therapeutic effects on neural progenitor and stem cells, astrocytes and the microglia/macrophages in the 7 th and 21 st days post-injury.

\section{Materials and Methods}

All procedures were approved by the Ethics Committee on Animal Experimentation (protocol number 38/2012) of Universidade Federal de Viçosa, affiliated to the National Organ (CONCEA).

\section{Animals}

Animals were housed in groups of five and maintained under controlled temperature and humidity, $12 \mathrm{~h}$ photoperiod, and were provided with water and commercial diet ad libitum.

Four other rats with 4 days of age were used to obtain bone marrow. Thirty male Wistar rats, three months old, weighing 250 to $300 \mathrm{~g}$ were submitted to spinal cord injury, then they were equally and randomly distributed into two groups. Animals from the treated group $(n=15)$ received bone marrow- 
derived MSCs, 1 x $10^{7}$ cells $/ \mathrm{mL}$ PBS/IV, three hours after injury. The control animals $(n=15)$ received intravenous injection of equivalent volume of PBS. No immunosuppressive therapy was undertaken.

Euthanasia was performed at 24 hours $(n=10), 7$ days $(n=10)$, and at 21 days $(n=10)$ post injury for removal of the spinal cord, lungs, and spleen.

\section{Mesenchymal stem cells culture and characterization}

The medullar canal of the femur of the four rats was washed with growth medium Dulbecco's Modified Eagle's Medium low glucose (Gibco, Grand Island/NY) containing 10-15 mM HEPES (Sigma-Aldrich, St. Louis, MO/USA) supplemented with $20 \%$ of serum fetal bovine (Gibco), $50 \mathrm{mg} / \mathrm{L}$ gentamicin (Sigma), 100,000 U/L of penicillin $\mathrm{G}$ potassium (Sigma) and $1.5 \mathrm{mg} / \mathrm{L}$ amphotericin B (Sigma). The material collected was centrifuged at $22^{\circ} \mathrm{C}, 1500 \mathrm{rpm}$, for 5 minutes. The supernatant was discarded and the pellet containing cells was resuspended in $5 \mathrm{~mL}$ DMEM. Were collected $100 \mu \mathrm{L}$ of the cell suspension mixed with an equal volume of trypan blue solution (Sigma) for counting in a Neubauer chamber and assessment of cell viability. The cells were grown in culture bottles in DMEM supplemented with $10 \%$ fetal bovine serum (FBS) in an incubator at $37^{\circ} \mathrm{C}$ with $5 \% \mathrm{CO}_{2}$.

Cells in the fourth passage were subjected to osteogenic and adipogenic differentiation. For osteogenic differentiation DMEM medium with $10 \%$ FBS was supplemented with $10-8 \mathrm{~mol} / \mathrm{mL}$ of dexamethasone (Sigma), $5 \mu \mathrm{g} / \mathrm{mLde}$ ascorbic acid 2-phosphate (Sigma) and $10 \mathrm{mmol} / \mathrm{L}$ of $\beta$-glycerophosphate (Sigma). For adipogenic differentiation DMEM medium without FBS was supplemented with $10-8 \mathrm{~mol} / \mathrm{mL}$ dexamethasone (Sigma), 10-8 M of human recombinant insulin, $200 \mu \mathrm{M}$ indomethacin crystalline and $500 \mu \mathrm{M}$ of isobutyl-methylxanthine. The differentiation medium was changed every 3 days during 28 days. Thereafter, cell samples were fixed for 1 hour in $4 \%$ paraformaldehyde and stained with Von Kossa to detect calcium deposits located in the matrix and Oil Red $\mathrm{O}$ to detect intracellular lipid vesicles.

For the immunophenotype evaluation, cell samples of the fourth passage were incubated with the primary antibodies anti-mouse CD11b clone M1/70, anti-mouse CD45 clone 69, anti-CD90 clone Ox-7 mouse, anti-CD73 clone 5 F/B9 mouse, antiCD54 clone 1A29 mouse and anti-HLA-DR (BD Bioscience, San Jose, CA, USA) for 30 minutes at $4^{\circ} \mathrm{C}$. Subsequently, cells were washed with PBS and incubated with secondary antibody conjugated to Alexa 488 fluorochrome under the same conditions. Samples were analyzed using FACScan flow cytometer and CellQuest ${ }^{\circledR}$ software.

\section{MSC nanolabeling and transplantation}

Cells of the fourth passage were incubated for 60 minutes at $37^{\circ} \mathrm{C}$ with 655 Qtracker $^{\circledR}$ Cell Labeling (Invitrogem, California, USA) according to manufacturer's recommendations. The labeled cells were trypsinized and centrifuged at $22^{\circ} \mathrm{C}, 1500$ rpm, for 5 minutes to obtain a pellet. This pellet was resuspended in PBS and aliquots of $1 \times 10^{7}$ cells $/ 1.0$ $\mathrm{mL}$ PBS were prepared, centrifuged and stored until the time of transplantation. Cells were delivered through an intravenous catheter (24G) inserted into the lateral tail vein. To validate the nanolabeling technique a single dose was freshly prepared for fluorescent microscopy observation.

\section{Induction of Spinal cord injury}

Animals were given fentanyl $(0.3 \mathrm{mg} / \mathrm{kg} / \mathrm{IM})$ for pain control and diazepam $(2.5 \mathrm{mg} / \mathrm{kg} / \mathrm{IP})$ for sedation. Induction to anesthesia and maintenance was provided with isoflurane. Antibioticotherapy with enrofloxacin $(10 \mathrm{mg} / \mathrm{kg} / \mathrm{IM})$ was administered as a single dose prior to the procedure. Dorsal laminectomy was performed on $\mathrm{T} 9$ and $\mathrm{T} 10$ vertebrae. To promote compressive spinal cord injury one catheter Forgaty was introduced into the epidural space and cranially directed until T8-T9. 
The cuff of the catheter was filled with $50 \mu \mathrm{L}$ of saline solution and maintained for five minutes to cause spinal cord compression. All animals were evaluated 24 hours after the procedure to assure that paraplegia was present. This was verified in all subjects. After surgery, analgesia with morphine was provided ( $5 \mathrm{mg} / \mathrm{Kg} / \mathrm{SC}$ ) q $4 \mathrm{~h}$ for 3 days.

\section{Morphology of spinal cord lesion}

At 7 and 21 days after spinal cord injury, 10 animals from each group were subjected to euthanasia using an overdose injection of thiopental sodium, intraperitoneal. Subsequently, the spinal cord was quickly removed from the spinal canal. A $2 \mathrm{~cm}$ fragment containing a macroscopic lesion in its center was cut and fixed in $4 \%$ buffered paraformaldehyde, $\mathrm{pH} 7.4$, and maintained at $4^{\circ} \mathrm{C}$ for 24 hours. After this period, the material was conditioned in alcohol $70 \%$ and processed for microscopic evaluation.

Prior to inclusion, samples were sectioned into three smaller fragments: cranial portion to the lesion, the lesion itself, and caudal portion to the lesion. The fragments were embedded in Paraplast ${ }^{\circledR}$ (Merck) and cross-sections of $6 \mu \mathrm{m}$ thick were made. In each histological slide 10 serial sections were positioned. These sections were cut with 60 $\mu \mathrm{m}$ interval in between. Some of these histological sections were randomly placed on ImmunoSlideEasyPath for immunological evaluation.

For light microscopy evaluation (Olympus BX-60 ${ }^{\circledR}$, Tokyo, Japan), slides were stained with hematoxylin-eosin and twelve images were taken per animal for posterior analysis.

The morphometric study considered the total cross sectional exterior area of the spinal cord and the injured area (which was enclosed within the total area and consisted of cystic formation, cavitation, gliosis, axonal edema and loss of tissue organization). The slides were visualized and the images captured using a light microscope (Olympus
BX-60®, Tokyo, Japan) connected to a digital camera (Olympus QColor-3®, Tokyo, Japan). Sixty fields from $\mathrm{H} \& \mathrm{E}$ (objective $\times 40$ ) were randomly chosen of each animal and a total of $4.37 \times 10^{6}$ $\mu \mathrm{m}^{2}$ of spinal cord area was analyzed. Then, the relationship between the injured area and the total area from each section was stablished (Software Image-Pro Plus 4.5, Media Cybernetics, Bethesda, USA).

Lungs and spleen were also included in Paraplast ${ }^{\circledR}$ (Merck) and sections of $6 \mu \mathrm{m}$ thick were made.

\section{Immunofluorescence}

The Q-tracker $655^{\circledR}$ immunofluorescence evaluation was done 24 hours after injury to assess the fate of transplanted cells in the injured spinal cord, lungs, and spleen using excitation filter WG.

Also, for evaluation in fluorescence microscopy, sections were deparaffinized in xylene and hydrated in decreasing concentrations of ethanol to water. Antigen recovery was performed in Citrate buffer $\mathrm{pH} 6.0$ (in water bath at $95^{\circ} \mathrm{C}$ ) for 50 minutes. After the antigen recovery, sections were washed with PBS-T (1X PBS $+1 \%$ Tween 20) once for 5 minutes, treated with blocking solution for 15 minutes. The following primary antibodies were used: anti-CD68 monoclonal antibody (ED1) (Santa Cruz, Cat. Sc59103) (diluted 1:50) for identification of monocytes and macrophages; polyclonal antibody produced in rabbit anti-glial fibrillary acidic protein (Invitrogen, Cat. 18-0063) (diluted 1:50), for identification of astrocytes; and polyclonal antibody produced in mouse anti-nestin (AbD Serotec, Cat. 6625-1010) (diluted 1:50) for identification of neural stem cell/ progenitor. The slides were incubated overnight at $4^{\circ} \mathrm{C}$. After treatment with the primary antibodies, the sections were washed three times with PBS and then incubated with secondary antibodies for 2 hours at room temperature. The secondary antibodies used were: anti-mouse IgG produced in goat and conjugated to DyLight ${ }^{\circledR} 488$ (AbD Serotec, Cat. STAR74D488GA) 1:100 dilution 
and anti-rabbit IgG conjugated with fluorescein isothiocyanate (FITC) (Sigma, Cat. F1262) diluted 1:100. The sections were then washed again with PBS and mounted with coverslips using mounting medium containing DAPI ${ }^{\circledR}$ (Vectashield mounting medium with DAPI, Vector Laboratories, Hercules, CA, USA).

To control the effectiveness of the immunoreactivity, for each slide, two histological sections were incubated with PBS instead of the solution containing the primary antibody.

Five images were captured per section using a fluorescence microscope (Olympus BX-60 ${ }^{\circledR}$, Tokyo, Japan). Labeled cells were quantified using the software Image-Pro Plus 4.5 software (Media Cybernetics, Bethesda, USA) using a grid with 143 points and the points of intersection containing cells were counted.

\section{Statistical analysis}

The quantitative data regarding the labeled cells using the immunofluorescent assessment were tested for normality using Kolmogorov-Smirnov test and then t-test. Data are presented as mean and standard error of the mean (SEM). Total area and injured area were assessed by the non- parametric Mann-Whitney $U$ test. A level of significance of $0.05(\alpha=5 \%)$ was adopted and descriptive levels ( $p)$ below this value were considered significant and represented by an asterisk $(*)$.

\section{Results}

Characterization of bone marrow-derived MSC

The number of mononuclear cells was always greater than the minimal recommended for initiating a cell culture and the initial viability of these cells was $91.80 \%$.

Cells presented a fibroblastoid appearance (Figures 1A and 1B) 48 hours after initial plating and throughout the evaluation period. Additionally, these cells presented elevated replication rates and were capable of adhering to the culture bottles.

Cells undergoing osteogenic differentiation showed the presence of calcified extracellular matrix by Von Kossa staining, observed at day 28, demonstrating its ability to differentiate into cells of bone lineage (Fig.1C). Cells cultured in medium supplemented for adipogenic induction presented at the end of the four weeks, intracellular lipid vesicles easily identifiable by Oil Red staining and light microscopy (Figure 1D).

The fourth passage MSCs were subjected to immunophenotyping with anti-CD11, anti-CD45, anti-CD54, anti-CD73, anti-CD90 and anti-HLADR and showed negative expression for surface markers CD11 (97.48\%), CD45 (96.98\%) and HLADR $(95.5 \%)$ and positive for the markers CD54 $(66.26 \%), \operatorname{CD} 73(86.82 \%)$ and CD90 (90.30\%) in the assessment by flow cytometry, as illustrated in Figure 2. 
Figure 1. Undifferentiated and differentiate MSC. (A) Cells presenting homogeneous distribution and $80 \%$ confluence, 48 hours after plating. (B) Highlights the fibroblastoid morphology cells. C) Osteogenic differentiation evidenced by Von Kossa staining and (D) Adipogenic differentiation evidenced by Oil Red O staining Bar: $50 \mu \mathrm{m}$.
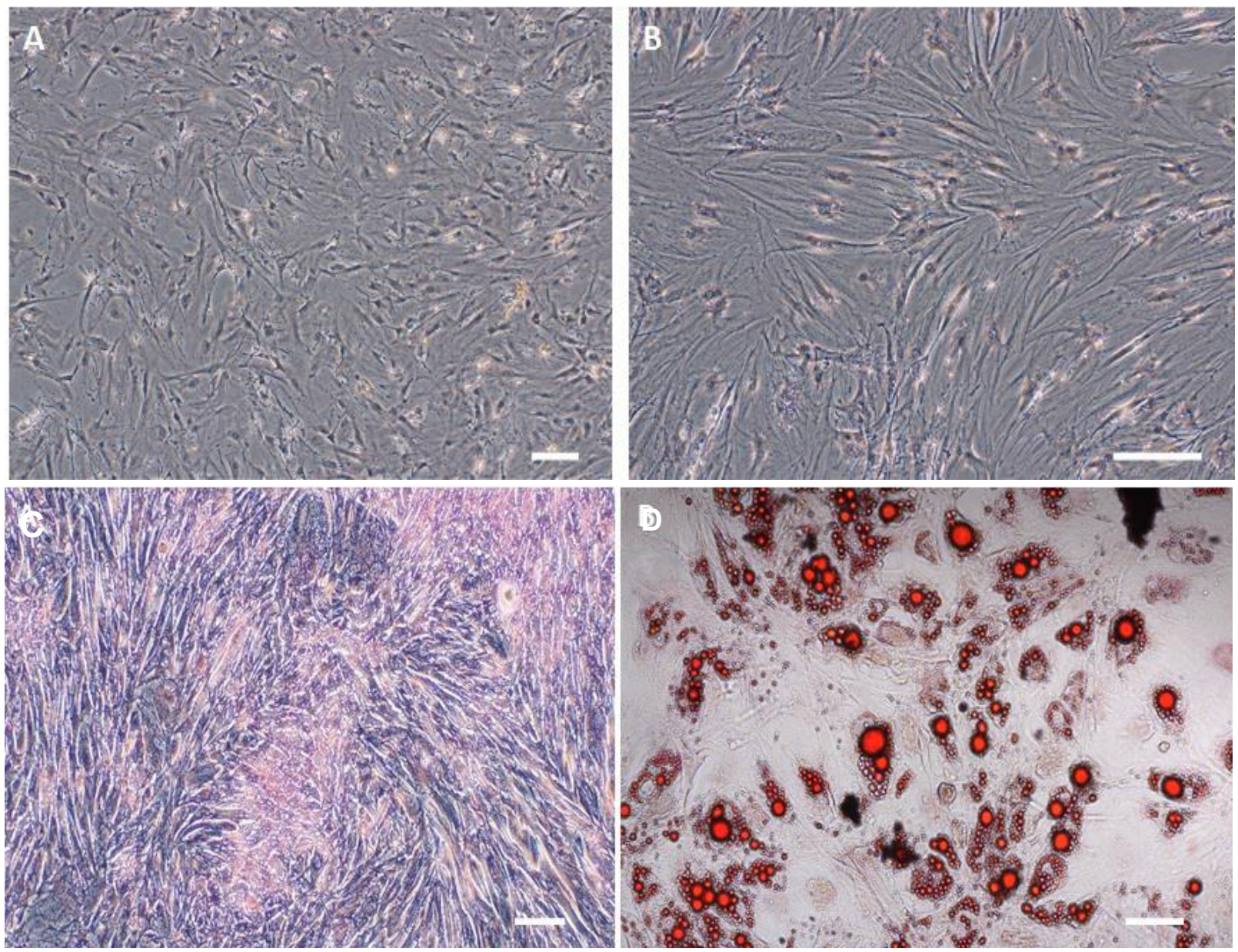
Figure 2. Immunophenotypic characterization of MSC by flow cytometry. Selected population showed $81.0 \%$ homogeneity. The fluorescence intensity of each marker of undifferentiated MSC (red line) is compared to isotype controls (black line) and is represented in percentage. The cell number is represented on the y axis and the intensity of the $\mathrm{x}$ axis.
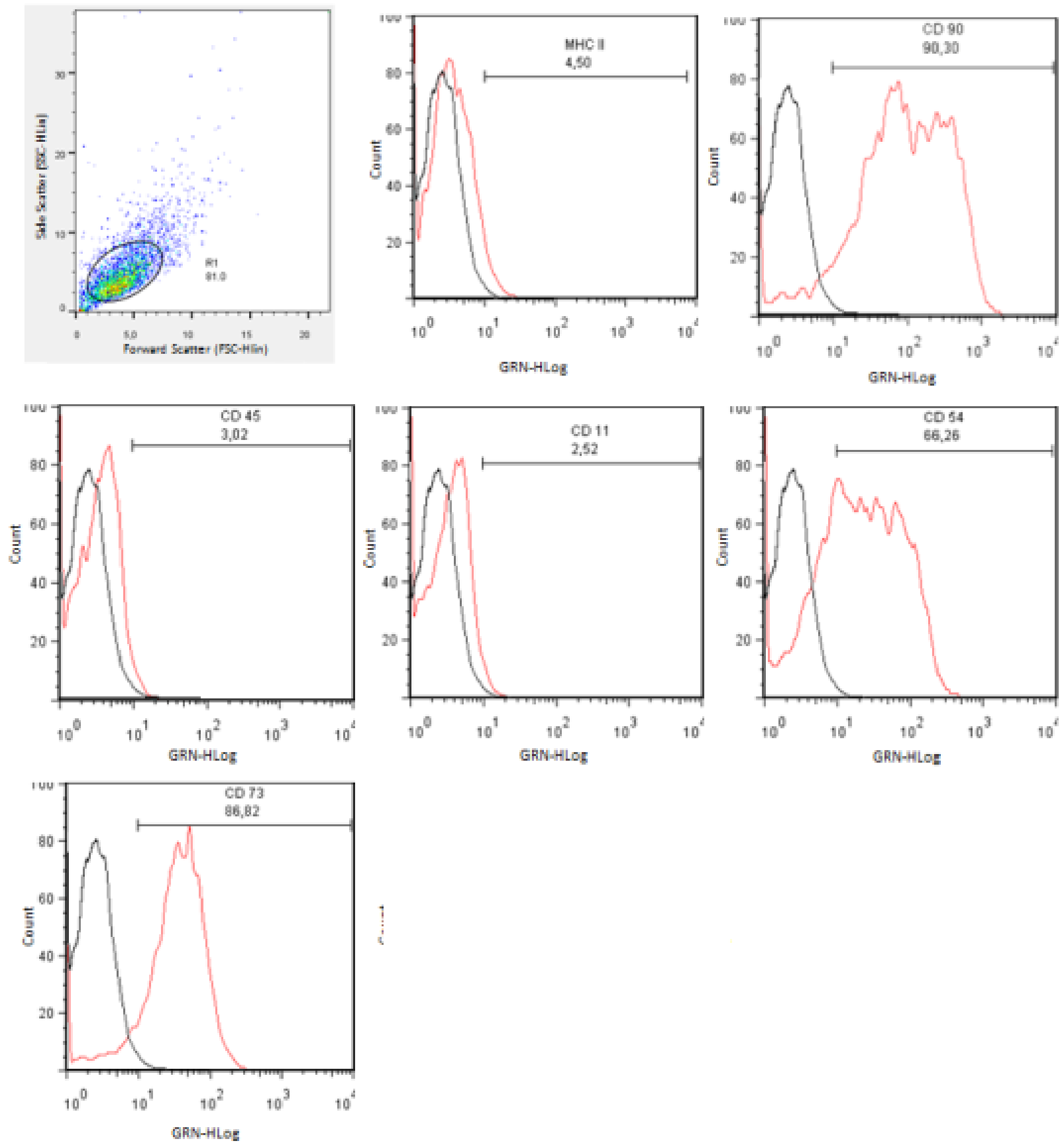


\section{MSC nanolabeling}

Cells demonstratively incorporated the marker because they emitted high cytoplasmic fluorescence (red) using the excitation filter WG. The nuclei (blue) are shown with excitation filter WU (Fig.3A).

\section{Fate of transplanted cells}

The transplanted labeled cells were tracked in various organs, including the injury site, at $24 \mathrm{~h}, 7$ and 21 days after injection and were only found in the lungs at the $24 \mathrm{~h}$ time point (Figure 3B).

Figure 3. Fluorescence microscopy images. (A) Photomicrograph of MSC after nano-labeling demonstrating cytoplasmic red fluorescence emitted by cells in suspension. Bar: $10 \mathrm{um}$. (B) Identification of the transplanted cells. The arrows indicate the MSC present in the lung 24 hours after injury. * represent the pulmonary alveoli. Nuclei $(\mathrm{N})$ were counter-stained with DAPI (blue). Bar: 50um.

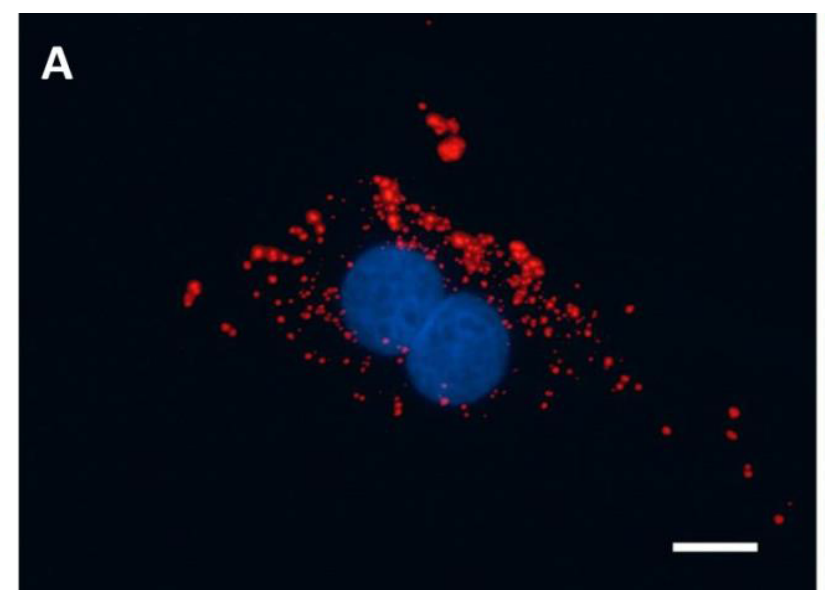

\section{Microscopic evaluation of the injured area}

The size of injury in the spinal cord was not different between the animals receiving MSC as

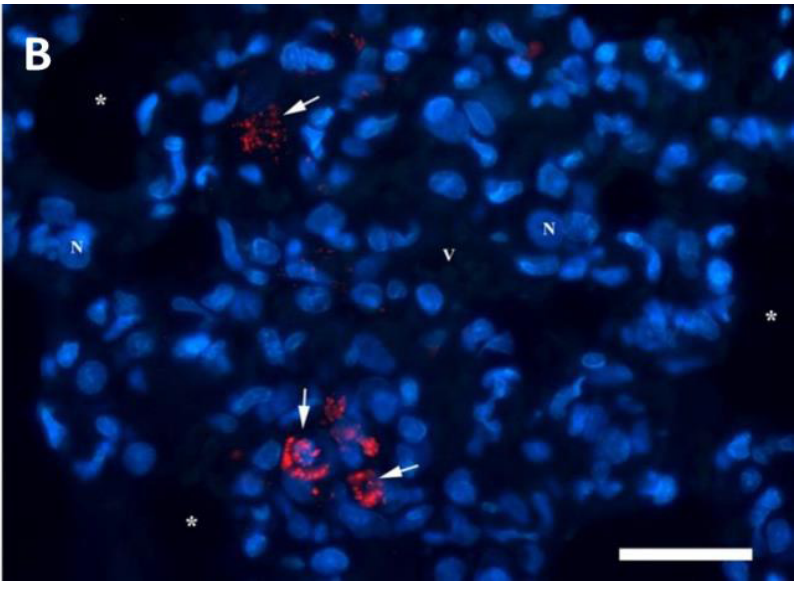

treatment and their controls. Both groups presented destruction of the gray and white matter with malacia, presence of gitter cells, and neuronal degeneration (Figure4) identified by light microscopy.

Figure 4. Representative image of spinal cord damage (A) assessed at 7 days post-injury. Area marked with * and delineated by the red line represents the area of the lesion and the black line delimits the total bone marrow area. Bar: $200 \mu \mathrm{m}$. (B) Enlargement of the lesion area showing intense malacia with gitter cells (arrows) and cavitation areas $(*)$. Bar: $50 \mu \mathrm{m}$.
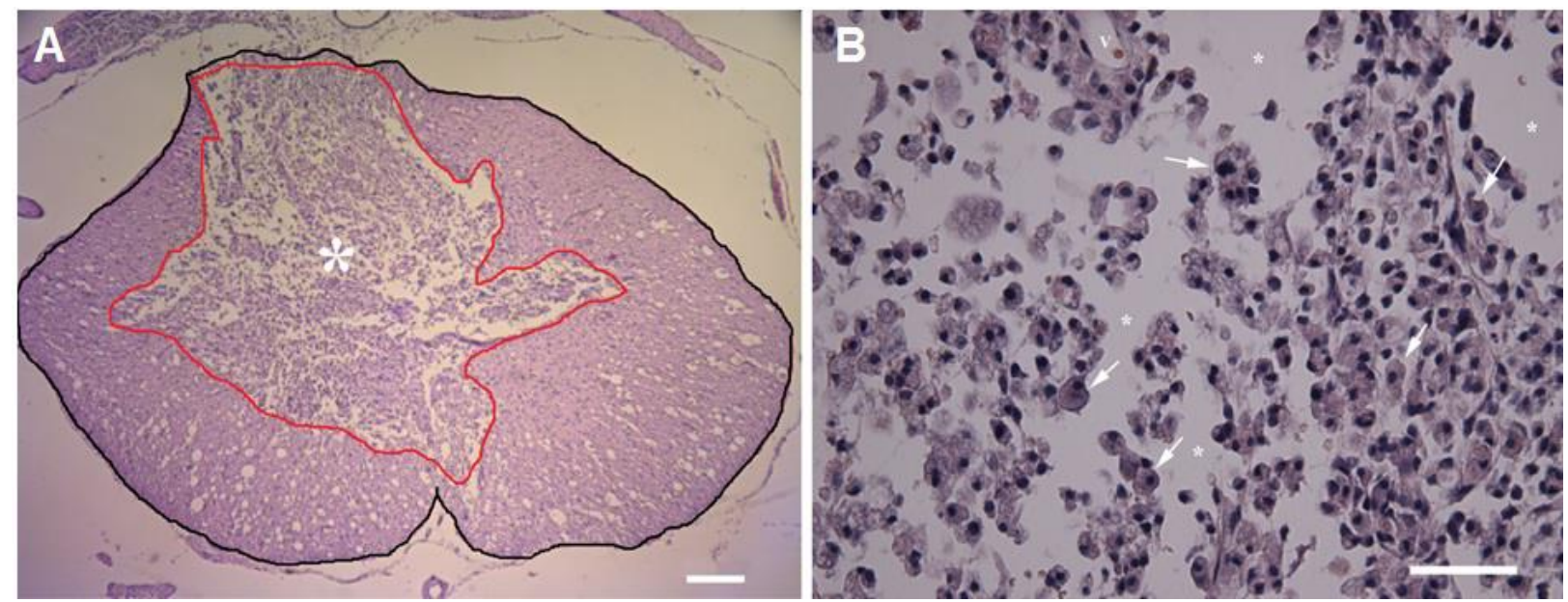


\section{Immunofluorescent evaluation}

The spinal cord injury resulted in activation of macrophages and microglia. Activated macrophages and microglia were characterized by their round morphology and immunoreactivity to CD68 (ED-1) in both groups.
CD68 positive cells $(\mathrm{CD} 68+)$ were concentrated mainly in the white matter and around the injured area. The treated group presented significant decrease of CD68+ compared to control. The mean immunoreactive area was $18.6 \% \pm 0.7$ and $9.3 \% \pm 0.6$, at 7 days, and $6.7 \pm 0.6 \%$ and $4.0 \% \pm 0.2$ at 21 days, for the control and treated groups respectively (Figure 5A and 5B).

Figure 5. Immunofluorescent evaluation of spinal cord injury. Representative immunofluorescence photomicrographs of markers (A) anti-CD68-macrophage/microglia, $(\mathbf{C})$ anti-GFAP-astrocytes and (E) anti-nestin-neural stem cells in spinal cord injury. Arrows indicate cells stained and "N" represents the cell nucleus counter-stained with DAPI (blue) Bar: $30 \mu \mathrm{m}$. (B), (D) and (F) represent the percentile of positively labeled cells. * indicates $\mathrm{p}<0.05$.
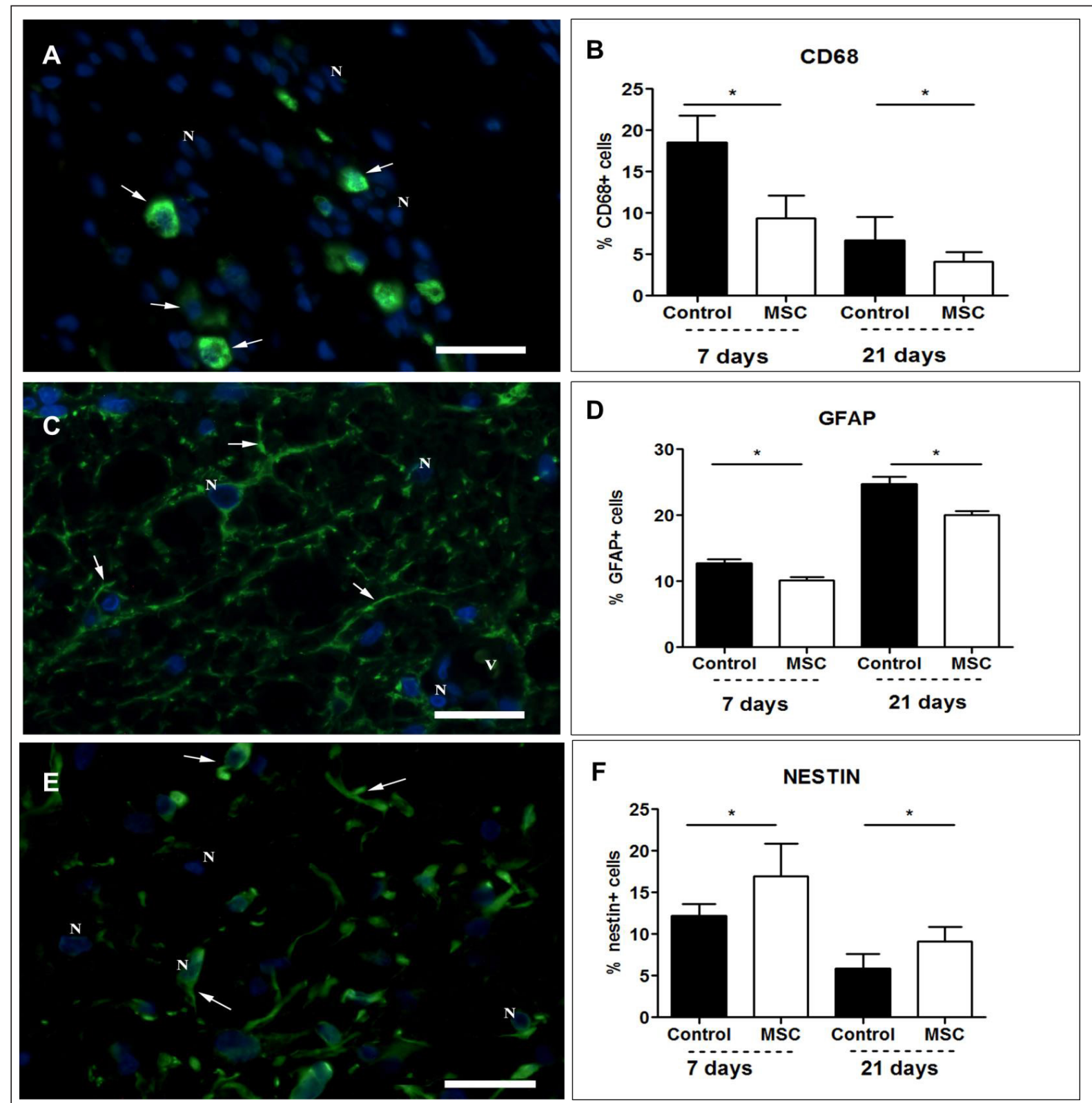
Following to the spinal cord injury, astrocytes became hypertrophic and reactive. The reactive astrocytes were characterized by their intense immunoreactivity to GFAP (glial fibrillary acidic protein). These astrocytes were mainly encountered in the periphery of the medulla and in the white matter around the injury in the dorso and dorsolateral portion of the medulla.

The GFAP immunoreactivity was significantly lower in the treated groups than in their controls. The mean value in the control group was $12.8 \% \pm 0.6$ and $10.1 \% \pm 0.5$ in the treated group, at 7 days. At day 21 post-injury, the immunoreactivity increased in both groups, however, the treated group remained with significantly lower values $(20.1 \% \pm 0.6)$ compared to the control $(24.8 \% \pm 1.0)$ (Figures 5C and 5D).

To evaluate the activation of neural stem cells/ progenitor at the site of spinal cord injury and the possible influence of MSC in this process, we used the anti-nestin marker. The analyzes showed that the neural stem cells/progenitor were activated at the lesion site in both groups. These cells were mainly found in the injured area (gray and white matter), and the treated group presented a significantly higher number of cells in both days, 7 and 21 postinjury. The percentage of labeled cells identified in the treated group was $17 \% \pm 0.8$ and $9.1 \% \pm 0.3$; and in the control group was $12.2 \% \pm 0.3$ and $5.9 \% \pm 0.3$, on days 7 and 21, respectively (Figures $5 \mathrm{E}$ and $7 \mathrm{~F}$ ).

\section{Discussion}

According to the International Society for Cellular Therapy (ISCT) there are three minimum requirements for a cell population to be classified as MSC: 1- be isolated from a population of mononuclear cells based on their selective adhesion in culture to plastic surface; 2- express CD13, CD29, CD54, CD73, CD90, CD106, and not express, in more than $95 \%$ of the cells in culture, CD34, CD45, CD14, CD11b, CD79, or CD19 and HLADR; and 3- must have the ability to differentiate, in vitro, into mesodermal lineages: bone, cartilage, and adipose tissue (MORRISON et al., 1997; NARDI; MEIRELLES, 2006). The cells cultured in this study showed a fibroblastoid morphology and adherence to the culture flask as described by Pittenger et al. (1999); showed positive expression of cell surface markers such as CD54, CD73 and CD90, and negative expression of CD11b, CD45 and MHC II; and underwent differentiation to bone and adipogenic lineage. Altogether, these fit the criteria for MSC classification, confirming that the cells used in this study were indeed MSC.

This study utilized MSC that were processed in laboratory, and as such they are hypoimmunogenic often lacking expression of HLA class II and costimulatory molecules; prevent the direct and indirect $\mathrm{T}$ cell response; and induce suppressive local microenvironment through prostaglandins and interleukins (MONTEIRO et al., 2010; GNECCHI et al., 2012). Thus, the allogenic MSC could be transplanted to individuals of incompatible major histocompatibility complexes, as done by Ryan et al. (2005).

The morphometric analyzes demonstrated that there was no size difference in the injured area of treated animals at 7 or 21 days post-injury. Similar results were described by Yoshihara et al. (2006) and Abrams et al. (2009) who also observed no significant reduction in the size of the lesion resulting from moderate spinal cord injury in rats treated with MSC. In contrast, other studies (ANKENY et al., 2004; BAKSHI et al., 2006; URDZIKOVA et al., 2006) reported a significant reduction in lesion area and greater preservation of white matter in treated animals, indicating neuroprotective effect of these cells. However, it must be emphasized that morphometric parameters should not be the sole criteria for assessing the effects of MSC in compressive spinal cord injury. Thus, our study provided additional information relative to the behavior of the cells involved in the repair process accompanied by the clinical improvement of the subjects. 
A spinal cord injury results in activation of macrophages/microglia resulting in intense inflammation and destruction to neurons, oligodendrocytes and astrocytes present in the area of injury. The process of inflammation after spinal cord injury has beneficial and detrimental effects (DONNELLY; POPOVICH, 2008), but several in vivo studies have shown that modulation of inflammation promoted improvements in motor and sensory functions (BETHEA et al., 1999; PARK et al., 2010). In the present study, we observed that the concentration of macrophages/microglia CD68+ within the injured area was significantly lower in the treated group, therefore the transplanted stem cells participated in the (regulation of?) the inflammatory process after spinal cord injury. This reduction in the concentration of macrophages/microglia CD68+ may have attenuated the deleterious secondary mechanisms caused by the inflammation and may be a factor related to the early functional restoration after spinal cord injury observed in previous studies.

Injuries to the central nervous system increase the intensity of labeling glial fibrillary acidic protein (GFAP) in astrocytic extensions (BIGNAMI; DAHL, 1994). This is described as fibrillar reactive astrocytosis and is associated with hyperplasia and hypertrophy of astrocytes. The reactive astrocytes form the glial scar that accumulates around the lesion forming a physical barrier and an inhibitory environment for axonal regeneration and remyelination (COUTTS; KEIRSTEAD, 2008). The significant reduction of the reactivity of astrocytes in the treated animals observed in this study suggests that MSC may have reduced the response of astrocytes and consequently may act by reducing the inhibitory effects of scar tissue providing a more permissive environment for axonal extension.

The neural stem cells are multipotent cells with potential to differentiate into neurons, astrocytes and oligodendrocytes (HSU et al., 2007) and the ependyma is known to be a rich source of these cells (MORENO-MANZANO et al., 2009). Nestin is a well-established marker for neural stem cell and precursor populations of proliferating cells in the CNS (WIESE et al., 2004). In the spinal cord of adult rats nestin + cells were found in multiple areas described as stem cell/progenitor cells niches (WEI et al., 2002). According Ronaghi et al. (2010), the recruitment of endogenous neural stem cells may be an alternative in spinal cord injury. Our results showed that MSC-treated group presented a greater amount of neural stem cells (nestin+) at the lesion site than the control. Thus, cell transplantation may have influenced the injure environment to provide signaling and growth factors to proliferation of endogenous stem cells as established by Urdzikova et al. (2006) and Rossi et al. (2010). Also, Wu et al. (2003) demonstrated functional recovery after transplantation of MSC and attributed this to increased differentiation of endogenous neural stem cells.

Efficacy and maintenance of cell nanolabeling, as well as cell viability were confirmed at the time of transplantation. These cells were found in the lungs 24 hours after injury. However, they were not found at the site of the lesion 24 hours, 7 or 21 days after injury, or in highly vascularized organs such as lungs or spleen after in 7 or 21 days. Other authors (SCHREPFER et al., 2007) also observed that, after IV infusion, the great majority of cells did not reach the organ of primary interest and were retained in the lungs.

One of the hypothesis that explains the retention of these cells in the lungs, could be attributed to the cell size in relation to the diameter of the capillaries in the lungs. A study evaluating a variety of cell diameters and the use of vasodilators revealed the imprisonment or the release of cells to the blood stream (SCHREPFER et al., 2007). The other hypothesis deals with the MSC's ability to adhere to the vascular endothelium. Ruster et al. (2006) suggested that ligand substances are involved with the adhesion and leakage of these cells. Fischer et al. (2009) believed in a receptor-mediated component located in the lungs, because when a second MSC bolus was administered a greater number of cells 
were captured in other organs besides lungs, suggesting that lung receptors were saturated.

These results do not exclude the possibility that the MSC retained in the lungs are capable of secreting protective factors. Others (MARTINO et al., 2011) observed tissue repairing in the CNS through mechanisms other than cell replacement such as trophic support and immunomodulation of endogenous repair.

MSC have been proven to provide potent trophic support (CAPLAN; DENNIS, 2006) with maintenance of tissue integrity and immunomodulation properties (WANG et al., 2009), thus having a broader scope than as mere replacement of cells. Hence, when administered intravenously, MSC act beyond increasing the expression of neurotrophic growth factors post injury (MAHMOOD et al., 2004), since they actually participate as bimodal cells, by providing immunomodulatory activity (CHICHA et al., 2013).

Apparently, there is a direct modulatory effect on immune cells that reside at the injury site, and a second immunomodulatory systemic effect. When evaluated as a whole these findings support the concept that both immune responses, local and systemic, are potentially important mechanisms of action of the MSC.

In our study, the MSC found in the lungs must have formed a niche capable of providing protection and immunomodulation. Therefore, suggesting that these MSC acted via secretion and not only by integration/differentiation within the host tissue. Similarly, Quertainmont et al. (2012) found no cell in the lesion. Nevertheless, beneficial effects on locomotion and a significant increase of nerve growth factor (NGF) expression in injured tissue, suggesting that MSC act through their secretions and not necessarily by integration/differentiation within the host tissue.

The evaluations performed in this study showed that the application of MSC intravenously has beneficial effects on the recovery of spinal cord trauma. The MSC contributed to attenuate the reactivity of astrocytes and activation of macrophages/microglia, and stimulated the activation of endogenous neural stem cells at the lesion site. Our results demonstrate the potential of the MSC to attenuate the immune response.

\section{Acknowledgements}

Conselho Nacional de Desenvolvimento Científico e Tecnológico (CNPq, Brazil), Coordenação de Aperfeiçoamento de Pessoal de Nível Superior), and Fundação de Amparo à Pesquisa do Estado de Minas Gerais (FAPEMIG, Brazil).

\section{Conflicts of interest}

None of the authors have any conflicts of interest to declare.

\section{References}

ABRAMS, M. B.; DOMINGUEZ, C.; PERNOLD, K.; REGER, R.; WIESENFELD-HALLIN, Z.; OLSON, L.; PROCKOP, D. Multipotent mesenchymal stromal cells attenuate chronic inflammation and injury-induced sensitivity to mechanical stimuli in experimental spinal cord injury. Restorative Neurology and Neuroscience, Amsterdam, v. 27, n. 4, p. 307-321, 2009.

ANKENY, D. P.; MCTIGUE, D. M.; JAKEMAN, L. B. Bone marrow transplants provide tissue protection and directional guidance for axons after contusive spinal cord injury in rats. Experimental Neurology, Orlando, v. 190, n. 1, p. 17-31, 2004.

BAKSHI, A.; BARSHINGER, A.; SWANGER, S.; MADHVANI, V.; SHUMSKY, J.; NEUHUBER, B.; FISCHER, I. lumbar puncture delivery of bone marrow stromal cells in spinal cord contusion: a novel method for minimally invasive cell transplantation. Journal of Neurotrauma, Larchmont, v. 23, n. 1, p. 55-65, 2006.

BETHEA, J. R.; NAGASHIMA, H.; ACOSTA, M. C.; BRICENO, C.; GOMEZ, F.; MARCILLO, A. E.; LOOR, K.; GREEN, J.; DIETRICH, W. D. Systemically administered interleukin-10 reduces tumor necrosis factor-alpha production and significantly improves functional recovery following traumatic spinal cord 
injury in rats. Journal of Neurotrauma, Larchmont, v. 16, n. 10, p. 851-863, 1999.

BIGNAMI, A.; DAHL, D. Glial cells in the central nervous system and their reaction to injury. $18^{\text {th }} \mathrm{ed}$. Austin: Tex, RG Landes, 1994. 220 p.

CAPLAN, A. I.; DENNIS, J. E. Mesenchymal stem cells as trophic mediators. Journal Cell Biochemistry, Hoboken, v. 98, n. 5, p. 1076-1084, 2006.

CHICHA, L.; SMITH, T.; GUZMAN, R. Stem cells for brain repair in neonatal hypoxia-ischemia. Childs Nervous System, Berlin, v. 30, n. 1, p. 37-46, 2013.

COUTTS, M.; KEIRSTEAD, H. S. Stem cells for the treatment of spinal cord injury. Experimental Neurology, Orlando, v. 209, n. 2, p. 368-377, 2008.

DONNELLY, D. J.; POPOVICH, P. G. Inflammation and its role in neuroprotection, axonal regeneration and functional recovery after spinal cord injury. Experimental Neurology, Orlando, v. 209, n. 2, p. 378-388, 2008.

FISCHER, U. M.; HARTING, M. T.; JIMENEZ, F.; MONZON-POSADAS, W. O.; XUE, W. H.; SAVITZ, S. I.; LAINE, G. A.; COX, C. S. Pulmonary passage is a major obstacle for intravenous stem cell delivery: the pulmonary first-pass effect. Stem Cells Development, Larchmont, v. 18, n. 5, p. 683-691, 2009.

GNECCHI, M.; DANIELI, P.; CERVIO, E. Mesenchymal stem cell therapy for heart disease. Vascular Pharmacology, New York, v. 57, n. 1, p. 48-55, 2012.

HSU, Y. C.; LEE, D. C.; CHIU, I. M. Neural stem cells, neural progenitors, and neurotrophic factors. Cell Transplantation, Elmsford, v. 16, n.2, p. 133-150, 2007.

KERN, S.; EICHLER, H.; STOEVE, J.; KLUTER, H.; BIEBACK, K. Comparative analysis of mesenchymal stem cells from bone marrow, umbilical cord blood, or adipose tissue. Stem Cells, Dayton, v. 24, n. 5, p. 12941301, 2006.

MAHMOOD, A.; LU, D.; CHOPP, M. Intravenous administration of marrow stromal cells (MSCs) increases the expression of growth factors in rat brain after traumatic brain injury. Journal of Neurotrauma, Larchmont, v. 21, n. 1, p. 33-39, 2004.

MARTINO, G.; BACIGA, L.; PERUZZOTTI-JAMETTI, L. Therapeutic stem cell plasticity orchestrates tissue plasticity. Brain, New York, v. 134, n. 6, p. 585-1587, 2011.

MONTEIRO, B. S.; ARGOLO, N. M.; DEL CARLO, R. J. Células-tronco mesenquimais. Ciência Rural, Santa Maria, v. 40, n. 1, p. 238-245, 2010.
MORENO-MANZANO, V.; RODRIGUEZ-JIMENEZ, F. J.; GARCIA-ROSELLO, M.; LAIINEZ, S.; ERCEG, S.; CALVO, M. T.; RONAGHI, M.; LLORET, M.; PLANELLS-CASES, R.; SÁNCHEZ-PUELLES, J. M.; STOJKOVIC, M. Activated spinal cord ependymal stem cells rescue neurological function. Stem Cells, Dayton, v. 27, n. 3, p. 733-743, 2009.

MORRISON, S. J.; SHAH, N. M.; ANDERSON, D. J. Regulatory mechanisms in stem cell biology. Cell, Cambridge, v. 88, n. 3, p. 471-488, 1997.

NARDI, N. B.; MEIRELLES, L. S. Mesenchymal stem cells: Isolation, in vitro expansion and characterization. Handbook Experimental Pharmacology, Berlin, v. 174, n. 2, p. 249-282, 2006.

PARK, W. B.; KIM, S. Y.; LEE, S. H.; KIMHW, P. J. S.; HYUN, J. K. The effect of mesenchymal stem cell transplantation on the recovery of bladder and hindlimb function after spinal cord contusion in rats. $B M C$ Neuroscience, London, v. 11, n. 1, p. 119-123, 2010.

PITTENGER, M. F.; MACKAY, A. M.; BECK, S. C.; JAISWAL，R. K.; DOUGLAS, R.; MOSCA, J. D.; MOORMAN, M. A.; SIMONETTI, D. W.; CRAIG, S.; MARSHAK, D. R. Multilineage potential of adult human mesenchymal stem cells. Science, Washington, v. 284, n. 1, p. 143-147, 1999.

QUERTAINMONT, R.; CANTINIEAUX, D.; BOTMAN, O.; SID, S.; SCHOENEN, J.; FRANZEN, R. Mesenchymal stem cell graft improves recovery after spinal cord injury in adult rats through neurotrophic and pro-angiogenic actions. Plos One, San Francisco, v.7, n. 6, p. e39500, 2012.

RONAGHI, M.; ERCEG, S.; MORENO-MANZANO, V.; STOJKOVIC, M. Challenges of stem cell therapy for spinal cord injury: human embryonic stem cells, endogenous neural stem cells, or induced pluripotent stem cells? Stem Cells, Dayton, v. 28, n. 1, p. 93-99, 2010.

ROSSI, S. L.; NISTOR, G.; WYATT, T.; YIN, H. Z.; POOLE, A. J.; WEISS, J. H.; GARDNER, M. J.; DIJKSTRA, S.; FISCHER, D. F.; KEIRSTEAD, H. S. Histological and functional benefit following transplantation of motor neuron progenitors to the injured rat spinal cord. Plos One, San Francisco, v. 5, n. 1, p. 1-15, 2010.

RUSTER, B.; GOTTIG, S.; LUDWIG, R. J.; BISTRIAN, R.; MULLER, S.; SEIFRIED, E.; GILLE, J. HENSCHLER, R. Mesenchymal stem cells display coordinated rolling and adhesion behavior on endothelial cells. Blood, Washington, v. 108, n. 12, p. 3938-3944, 2006. 
RYAN, J. M.; BARRY, F. P.; MURPHY, J. M.; MAHON, B. P. Mesenchymal stem cells avoid allogeneic rejection. J. Inflammation, London, v. 2, n. 1, p. 2-8, 2005.

SAHNI, V.; KESSLER J. A. Stem cell therapies for spinal cord injury. Nature Reviews Neurology, London, v. 6, n. 7, p. 363-372, 2010.

SAUNDERS, L.; SELASSIE, A.; HILL, E.; NICHOLAS, J.; VARMA, A.; LACKLAND, D.; PATEL, S. Traumatic spinal cord injury mortality. 1981-1998. Journal Trauma, Baltimore, v. 66, n. 2, p. 184-90, 2009.

SCHREPFER, S. T.; DEUSE, H.; REICHENSPURNER, M. P.; FISCHBEIN, R. C.; ROBBINS; PELLETIER, M. P. Stem cell transplantation: the lung barrier. Transplantation Proceedings, New York, v. 39, n. 2, p. 573-576, 2007.

URDZIKOVA, L.; JENDELOVA, P.; GLOGAROVA, K.; BURIAN, M.; HAJEK, M.; SYKOVA, E. Transplantation of bone marrow stem cells as well as mobilization by granulocyte-colony stimulating factor promotes recovery after spinal cord injury in rats. Journal of Neurotrauma, Larchmont, v. 23, n. 9, p. 1379-1391, 2006.

WANG, M.; YANG, Y.; YANG, D.; LUO, F.; LIANG, W.; GUO, S.; XU, J. The immunomodulatory activity of human umbilical cord blood-derived mesenchymal stemcells in vitro. Immunology, Oxford, v. 126, n. 2, p. 220-232, 2009.
WEI, L. C.; SHI, M.; CHEN, L. W.; CAO, R.; ZHANG, P.; CHAN, Y. S. Nestin-containing cells express glial fibrillary acidic protein in the proliferative regions of central nervous system of postnatal developing and adult mice. Brain Research Development, Amsterdam, v. 139, n. 1, p. 9-17, 2002.

WIESE, C.; ROLLETSCHEK, A.; KANIA, G.; BLYSZCZUK, P.; TARASOV, K. V.; TARASOVA, Y; WERSTO, R. P.; BOHELER, K. R.; WOBUS, A. M. Nestin expression: a property of multi-lineage progenitor cells? Cellular and Molecular Life Sciences, Basel, v. 61, n. 19-20, p. 2510-2522, 2004.

WU, S.; SUZUKI, Y.; EJIRI, Y.; NODA, T.; BAI, H.; KITADA, M.; KATAOKA, K.; OHTA, M.; CHOU, H.; IDE, C. Bone marrow stromal cells enhance differentiation of cocultured neurosphere cells and promote regeneration of injured spinal cord. Journal Neuroscience Research, New York, v. 72, n. 3, p. 343351, 2003.

YOSHIHARA, H.; SHUMSKY, J. S.; NEUHUBER, B.; OTSUKA, T.; FISCHER, I.; MURRAY, M. Combining motor training with transplantation of rat bone marrow stromal cells does not improve repair or recovery in rats with thoracic contusion injuries. Brain Research, Amsterdam, v. 1119, n. 1, p. 65-75, 2006. 